\title{
/COMMENTARY
}

by Bernard Dixon

\section{IRRATIONALITY IN THE EUROPEAN COMMUNITY}

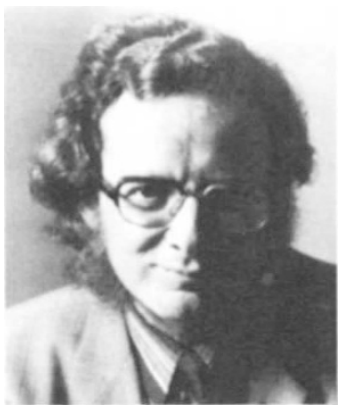

Trationality has won the day. Despite the British Veterinary Association's valiant efforts, which I described last month, to educate the public and the politicians about hormones, the use of these substances as animal growth promoters is to be prohibited throughout the European Community.

Surrounded by anger, dismay, and disbelief, the Common Market's agriculture ministers have rejected their own expert committee's advice and settled on a ban that will come into effect on January 1, 1988. Britain-the only country actively opposed to the move-may challenge the ruling's validity before the European Court of Justice. But given the ferocity of the political campaign which led to this Brussels debacle, together with the curious status of otherwise objective evidence in the legal domain, I am not sanguine about the prospects for a reversal.

Whatever the early economic implications of the EEC action, biotechnologists must heed far more disquieting long-term lessons from a sequence of events that has seen objective scientific findings thrown out the window in favour of mindless sentiment. A few years ago, the EEC's Veterinary Products Committee, chaired by Eric Lamming of Nottingham University, was asked to re-investigate suspicions of risks to human health associated with the use of hormones to fatten farm animals. After processing a formidable quantity of data, the committee reported that progesterone, testosterone, and estradiol posed no such dangers. But, while continuing their studies of the remaining two substances (trenbolone and zeranol), Lamming and his colleagues suddenly found their work curtailed. Lobbied aggressively by the European Consumers Association, EEC agriculture ministers had grown impatient of science's painstaking methods and had resolved upon what U.K. Prime Minister Harold Wilson once termed "the smack of firm government." The result: a ban not only considered unnecessary by the EEC's own specialist panel, but one that also flies in the face of evidence from prestigious bodies as disparate as the U.S. Food and Drug Administration and the World Health Organization.

Not suprisingly, after its rear-guard attempts to counter hysteria with sanity, the BVA responded with uncharacteristic fury to the EEC decision. "By refusing to consider the scientific evidence marshalled by Professor Lamming, and indeed by remaining unpersuaded by the mass of earlier data, the European Commission has demonstrated that its reasons for banning growth promoters are political, influenced by fringe consumer groups using an emotional appeal. Consumers in this country will have to foot the bill, in the form of dearer meat, to satisfy the prejudiced view of the extremists," said the Association's journal, The Veterinary Record (118:1, 1986).

To be fair even in the face of absurdity, we have to accept that it is on economic grounds that a ban does have slender justification. In short, moves to slow down the rate at which animals grow might be expected to reduce the massive meat surpluses which are such an expensive embarrassment to Europe at the present time. But that is not the principal basis upon which the ban has been imposed. The real background was enunciated all too clearly in London earlier this year by the EEC's agricultural commissioner, Frans Andriessen. It was, he said, entirely proper for politicians to pay more attention to "political realities" than to the facts of science. As is now widely argued in regard to nuclear power stations, what counts is not the actual danger behind a particular scientific development-whether significant, remote, or non-existentbut public perception of that danger.

Immediate implications of the hormone ban are clearnot least a considerable, costly increase in meat testing at abattoirs, and the likelihood that a black market will begin to operate (possibly extending to cheaper, genuinely dangerous substances such as the stilbenes). For industry, however, the most serious consequences have a more extensive time horizon. The European market for growth hormones is sufficiently modest in size that even companies commanding a large share of that market, such as Hoechst, are hardly faced with commercial disaster. But they are now exercised by the nightmare prospect that similar political decisions could mean the abrupt loss of gargantuan sums invested in the development and licensing of other new products in future.

Consider the research now proceeding apace in several laboratories on bovine growth homone $(\mathrm{bGH})$ produced by recombinant DNA techniques. Work carried out by the U.K. Agricultural and Food Research Council (AFRC) has shown that one such genetically engineered bGH (which is physiologically inactive in humans) is spectacularly effective in promoting the formation of lean tissue and improving the efficiency of food conversion in young animals. Lambs given the hormone put on 24 percent more muscle than controls, accompanied by a 12.5 -percent decrease in fat. Preliminary results point to another benefit too. Ruminants secrete more growth hormone during energy deficit, thereby conserving body protein at the expense of fat. Now, it seems, administration of additional bGH to lactating dairy cows can stimulate substantial increases in milk yield.

Until the Brussels debacle, there were high hopes that substances of this sort would be on the market within a few years. Whether that will happen is now an open question. Giving evidence to a House of Lords select committee before the agriculture ministers took their woeful decision, Professor John Prescott, director of the AFRC's Grassland Research Institute, warned that such a ban would render all of this work worthless. I fear he has been proved right. And I wonder how many more products of biotechnology could be stillborn if those responsible for them, and for the health of the scientific enterprise generally, do not take vigorous, educative, and political action before it is too late.

Bernard Dixon, Ph.D., is a contributing editor of Bio/ Technology. 